\title{
Helicobacter pylori recombinant UreG protein: cloning, expression, and assessment of its seroreactivity
}

\author{
Akbar Khalilpour ${ }^{1}$, Sabariah Osman', Muhammad Hafiznur Yunus ${ }^{1}$, Amutha Santhanam¹, Nagarajan Vellasamy ${ }^{2}$ \\ and Rahmah Noordin ${ }^{1 *}$
}

\begin{abstract}
Background: Helicobacter pylori is a human pathogen and during the process of infection, antigens from the bacterium elicit strong host humoral immune responses. In our previous report, native H. pylori UreG protein showed good reactivity with sera from $\mathrm{H}$. pylori patients. This study was aimed at producing the recombinant form of the protein ( $\mathrm{r} U \mathrm{reG}$ ) and determining its seroreactivities.

Methods: The coding sequence of $H$. pylori UreG was cloned and the recombinant protein expressed and purified by affinity chromatography using nickel nitrilotriacetic acid (Ni-NTA) resin. The antigenicity of rUreG to detect H. pylori specific antibodies was determined by western blot, using HRP-conjugated anti-human IgG and IgA antibodies as probes. A total of 70 sera, comprising 30 positive and 40 control serum samples, were used. The positive sera were from culture-positive H. pylori-infected patients with duodenal ulcers, gastric ulcers, or gastritis. The control sera comprised three types of samples without detectable H. pylori antibodies, i.e. healthy individuals (with no history of gastric disorders) ( $n=10)$; patients who attended an endoscopy clinic (because of gastrointestinal complaints) but were H. pylori culture negative $(n=20)$; and people with other diseases $(n=10)$. Additionally, hyperimmune mice serum against rUreG was raised and tested with the native and recombinant UreG protein.

Results: The ureG gene fragment was successfully cloned and expressed in both soluble and insoluble forms. Western blots on rUreG protein showed 70\% (21/30) and 60\% (18/30) reactivity with patients' sera when probed with HRP-conjugated anti-human IgG and IgA antibodies, respectively; and the combination of the IgG and IgA western blots showed reactivity of $83.3 \%$ (25/30). By comparison, $97.5 \%$ and $92.5 \%$ of the control sera showed no reactivity when probed with HRP-conjugated anti-human IgG and IgA antibodies, respectively. Both the H. pylori lysate antigen and rUreG protein displayed a distinctive band at the expected molecular weight when probed with the hyperimmune mice serum.

Conclusion: The rUreG protein was successfully cloned and expressed and showed good reactivity with $\mathrm{H}$. pylori culture-positive patients' sera and no reactivity with most control sera. Thus, the diagnostic potential of this recombinant protein merits further investigation.
\end{abstract}

Keywords: Helicobacter pylori, UreG, Cloning, Expression, Recombinant protein, Seroreactivity

\footnotetext{
* Correspondence: rahmah8485@gmail.com

${ }^{1}$ Institute for Research in Molecular Medicine (INFORMM), Universiti Sains

Malaysia, 11800, Minden, Penang, Malaysia

Full list of author information is available at the end of the article
} 


\section{Background}

Helicobacter pylori is a helical- or spiral-shaped, microaerophilic, Gram-negative bacterium that colonizes the apical side of human gastric epithelial cells and mucous layers [1]. The discovery and successful culture of $H$. pylori by Marshall and Warren in 1982 revolutionized the diagnosis and treatment of gastroduodenal disease [2]. This organism has been categorized as a class I carcinogen by the World Health Organization [3,4] and direct evidence of carcinogenesis was recently demonstrated in an animal model. H. pylori infection is associated with peptic ulcer diseases such as gastric or duodenal ulcer, atrophic gastritis, gastric cancer, and mucosa-associated lymphoid tissue lymphoma [2,5]. Hence, the identification and prevention and/or treatment of $H$. pylori infection can prevent considerable mortality resulting from chronic infection. During the process of $H$. pylori infection, the antigens secreted from the bacterium elicit strong antibody responses in the host; thus, secreted $H$. pylori antigens may be studied as potential infection biomarkers [6]. Various $H$. pylori proteins had been employed as infection markers for diagnosis, such as CagA, VacA, HspB, FlaA, FlaB, and UreC $[7,8]$.

On initial infection of gastric cells, the host responds strongly to the presence of $H$. pylori through both the innate and acquired immune systems. Antigen-presenting $B$ cells differentiate into plasma cells, which produce antibodies such as IgA, IgG, and IgM as the second line of defense, with IgA as the first antibody secreted $[9,10]$. During the early stages of $H$. pylori infection, IgM antibodies are secreted by plasma cells before there is a sufficient titer of IgG in the blood [6]. Human studies have shown that the presence of anti-H. pylori IgA in maternal milk is associated with delayed colonization in infants, suggesting that IgA can block infection. In another study by Argent and Atherton (2007), IgG antibodies proved to be a useful tool for the serodiagnosis of $H$. pylori infection [11]. In summary, these studies suggested that anti-H. pylori antibodies can be used for diagnosis, to reduce infection and, by inference, could be an effector mechanism in prophylactic vaccination as well. During $H$. pylori infection, antibodies of the classes IgG and IgA can be detected, while IgM antibodies have been found to have little diagnostic utility. This may be explained by the fact that H. pylori infection is a chronic condition and IgM antibody is secreted in the acute phase of infection [12].

One approach to identify antigen candidates for diagnostic purposes is to isolate the bacterium from the biopsy samples of patients and use the antisera from the patients to screen for reactive proteins in western blot analysis. This would then be followed by purification of the immunoreactive proteins, determination of the amino acid sequence, nucleotide sequence elucidation, cloning, and recombinant protein expression [13].
Using a similar approach, Khalilpour et al. (2013) studied a local (Malaysian) H. pylori isolate to identify potential diagnostic markers. Four protein bands were identified by western blot analysis using IgG from serum samples of culture-positive patients and control sera [14]. Out of the four proteins identified (UreG, UreB, CagI, and pyrroline-5-carboxylate dehydrogenase), UreG was selected for further work because it is a novel protein in terms of potential utility for diagnosis. It is also an interesting protein because it is frequently required to complete the biosynthesis of nickel enzymes [15]. In the present study, the UreG protein was investigated further. We report the cloning and expression of the UreG coding sequence and determination of its seroreactivity.

\section{Methods}

\section{Ethical approval}

Written informed consent from the patient was obtained for use of his duodenal biopsy sample in this study. In addition written informed consents were obtained from each patient prior to collection of their serum samples. Approval for this study was obtained from the Universiti Sains Malaysia Human Research Ethics Committee (Ref no: USMKK/PPP/JEPeM [214.3.4]). This approval included the collection and use of the $H$. pylori strain isolated from the human duodenal biopsy sample, the collection and use of serum samples and the use of stored control serum samples. The use of mice in this study was approved by Universiti Sains Malaysia Animal Research Ethics Committee [Ref. no: USM/Animal Ethics Approval/2012 (75) (407)].

\section{Bacterial culture and extraction of genomic DNA}

The H. pylori strain used in this study (HpUSM3121108) was isolated from a human duodenal biopsy sample obtained from a patient with a duodenal ulcer at the Sebarang Jaya Hospital, Penang, Malaysia. H. pylori was cultured on tryptic soy blood agar with 5\% defibrinated sheep blood under microaerophilic conditions $(10 \%$ $\mathrm{CO}_{2}, 5 \%$ oxygen, $85 \%$ nitrogen in air) at $37^{\circ} \mathrm{C}$ for $5-$ 7 days $[16,17]$. The bacterial cells were aseptically harvested by adding $3 \mathrm{~mL}$ phosphate-buffered saline (PBS, $\mathrm{pH}$ 7.2) to the agar plate; the bacterial suspension from the plate was then collected and placed in a $10-\mathrm{mL}$ centrifuge tube, and centrifuged at $3000 \times g$ at $4^{\circ} \mathrm{C}$ for $15 \mathrm{~min}$. The pellet was washed by resuspending in $1 \mathrm{~mL}$ of PBS, transferred into a $1.5-\mathrm{mL}$ microcentrifuge tube, followed by centrifugation at $11,000 \times g$. The washing step was repeated twice, then the final fresh bacterial cell pellet was used for genomic DNA extraction using the Bacterial Genomic DNA Extraction Kit (DNeasy; Qiagen, Hilden, Germany). The DNA was suspended in TE buffer and stored at $-20^{\circ} \mathrm{C}[18,19]$. 


\section{DNA amplification}

The sequence of the ureG gene was deposited in the GenBank database with accession number KC576840 [20]. The ure $G$ gene was amplified by polymerase chain reaction (PCR) using a forward primer containing a HindIII restriction site and a reverse primer containing an EcoRI site: $5^{\prime}$-AAG CTT TCA ATC TTC CAA TAA AGC GTT G-3' and 5'-GAA TTC ATG GTA AAA ATT GGA GTT TGT GG-3'. PCR was performed in an automatic thermal cycler using a $50-\mu \mathrm{L}$ reaction mixture containing $7 \mu \mathrm{L}$ of $10 \times$ PCR buffer, $3 \mu \mathrm{L}$ of sample DNA, $1 \mu \mathrm{L}$ of $10 \mathrm{mmol} / \mathrm{L}$ dNTPs, $2 \mu \mathrm{L}$ of $20 \mathrm{pmol} / \mathrm{L}$ primers, and $2.5 \mathrm{U}$ of Taq polymerase. The mixture was incubated for $2 \mathrm{~min}$ at $94^{\circ} \mathrm{C}$ for initial denaturation of the target DNA, then 35 cycles of denaturation at $94^{\circ} \mathrm{C}$ for $1 \mathrm{~min}$, annealing at $53.8^{\circ} \mathrm{C}$ for $1 \mathrm{~min}$, and elongation at $72^{\circ} \mathrm{C}$ for $2 \mathrm{~min}$. The amplified products $(5 \mu \mathrm{L})$ were analyzed by agarose electrophoresis and then visualized under ultraviolet light.

\section{Recombinant plasmid construction and purification}

The PCR product was purified using the PCR Fragment Recovery Kit (Promega, Madison, WI, USA). In preparation for cloning, an A-tailing reaction was performed. The reaction mixture comprised $10 \mu \mathrm{L}$ of purified PCR product, $1 \mu \mathrm{L}$ of $10 \times$ PCR buffer (with $\mathrm{MgCl}_{2}$ ), $1 \mu \mathrm{L}$ of $12.5 \mathrm{mmol} / \mathrm{L}$ of dATP, and $3.75 \mathrm{U}$ of Taq polymerase. After incubation at $72^{\circ} \mathrm{C}$ for $30 \mathrm{~min}$, the A-tailed PCR product was cloned in the $\mathrm{pCR}^{\circ} 2.1$-TOPO vector supplied in the $\mathrm{TOPO}^{\mathrm{m}}$-TA Cloning Kit (Invitrogen, Carlsbad, CA, USA). The reaction contained $4 \mu \mathrm{L}$ of purified PCR product, $1 \mu \mathrm{L}$ of salt solution, $1 \mu \mathrm{L}$ of $\mathrm{pCR}^{\circ} 2.1$-TOPO vector, and $1 \mu \mathrm{L}$ of water (Bioline, USA). The reaction mixture was then transformed into TOP10F Escherichia coli and positive clones were selected on agar containing X-gal and identified by PCR and restriction enzyme digestion. A single positive bacterial colony was cultivated in $3 \mathrm{~mL}$ of LB broth containing $100 \mathrm{mg} / \mathrm{L}$ of ampicillin, with shaking (300 rpm), at $37^{\circ} \mathrm{C}$ overnight. Recombinant plasmids (TOPO $\%$ ureG) were extracted using the DNA Purification Kit (Promega) and checked by PCR and restriction endonuclease digestion.

For sub-cloning into the pRSET vector (Invitrogen), endonuclease digestion was performed on the TOPO $\%$ ureG recombinant plasmids and pRSET version "a" (Invitrogen) to generate fragments with EcoRI and HindIII digestion sites. Then, a ligation reaction was prepared, which consisted of $17 \mu \mathrm{L}$ of gel-purified insert, $1 \mu \mathrm{L}$ of pRSET vector, $2 \mu \mathrm{L}$ of DNA dilution buffer, and $10 \mu \mathrm{L}$ of rapid ligation buffer. The reaction was started by adding 5 $\mathrm{U}$ of T4 DNA ligase, the mixture was mixed by pipetting and then incubated at $15-25^{\circ} \mathrm{C}$ for $5 \mathrm{~min}$. The circular recombinant plasmid was then transformed into a competent expression host [E. coli BL21 (DE3) pLysS] (Invitrogen) and plated onto LB agar which contained $100 \mu \mathrm{g} / \mathrm{mL}$ of ampicillin and $35 \mu \mathrm{g} / \mathrm{mL}$ of chloramphenicol. DNA sequencing of the cloned and sub-cloned ureG gene of the recombinant plasmid was performed by the Centre for Chemical Biology (CCB) at Universiti Sains Malaysia. The nucleotide and amino acid sequences were then analyzed using the BioEdit software (Ibis Biosciences, Carlsbad, USA) and compared with published sequences in the public databases.

\section{Expression of recombinant protein}

A pre-culture was first established by inoculating a single colony of the recombinant bacteria from a freshly subcultured LB plate (containing $100 \mu \mathrm{g} / \mathrm{mL}$ of ampicillin and $35 \mu \mathrm{g} / \mathrm{mL}$ of chloramphenicol) into $100 \mathrm{~mL}$ of Terrific broth (TB) containing the same antibiotics as above, followed by overnight incubation at $37^{\circ} \mathrm{C}$, with shaking $(180 \mathrm{rpm})$. The TB was prepared by dissolving $12 \mathrm{~g}$ bacto-tryptone, $24 \mathrm{~g}$ yeast extract, and $4 \mathrm{~mL}$ glycerol in $900 \mathrm{ml}$ deionized water, then autoclaving. The TB was then made up to $1 \mathrm{~L}$ with salt solution prior to use. The salt solution was prepared by dissolving $125.4 \mathrm{~g}$ dipotassium hydrogen phosphate $\left(\mathrm{K}_{2} \mathrm{HPo}_{4}\right)$ and $23.1 \mathrm{~g}$ potassium dihydrogen phosphate $\left(\mathrm{KH}_{2} \mathrm{PO}_{4}\right)$ in $1 \mathrm{~L}$ deionized water, then autoclaving.

For large-scale expression, $4 \mathrm{~L}$ (eight 500-mL cultures in 1-L flasks) of fresh TB were used. Each flask was inoculated with $25 \mathrm{~mL}$ of the above pre-culture and incubated at $37^{\circ} \mathrm{C}$, with shaking $(200 \mathrm{rpm})$ until the $\mathrm{OD}_{600}$ reached 0.5 . The recombinant bacteria were induced to express recombinant UreG (rUreG) by the addition of $1 \mathrm{mM}$ isopropyl $\beta$-D-1-thiogalactopyranoside (IPTG; Fermentas, Hanover, MD, USA), followed by incubation at $37^{\circ} \mathrm{C}$, with shaking (200 rpm), for $4.5 \mathrm{~h}$. The cells were then harvested by centrifugation at $10,000 \times \mathrm{g}$ at $4^{\circ} \mathrm{C}$ for $10 \mathrm{~min}$. The cell pellet was resuspended in $10 \mathrm{~mL}$ of lysis buffer (containing $10 \mathrm{mM}$ imidazole and $0.1 \%$ Triton-X 100), lysozyme $(0.5 \mathrm{mg} / \mathrm{mL}$; Amresco, Solon, OH, USA), and a cocktail of protease inhibitors $(14.8 \mu \mathrm{g} / \mathrm{mL}$; Roche Applied Science, Indianapolis, IN, USA), incubated on ice for $30 \mathrm{~min}$, followed by lysis using a French press $40 \mathrm{~K}$ (Thermo Spectronic, Rochester, NY, USA). The supernatant (containing soluble protein) and the pellet (containing inclusion bodies) were separated by centrifugation at $10,000 \times g$ at $4^{\circ} \mathrm{C}$ for $10 \mathrm{~min}$, and both components were retained for subsequent procedures.

\section{Purification of rUreG under native conditions}

DNaseI was added $(5 \mu \mathrm{g} / \mathrm{mL})$ to the supernatant (prepared as above), incubated on ice for 10-15 min, centrifuged at $10,000 \times g$ at $4^{\circ} \mathrm{C}$ for $30 \mathrm{~min}$, and then syringe filtered $(0.45 \mu \mathrm{m})$. Finally, the supernatant was incubated with $1 \mathrm{~mL}$ of washed nickel nitrilotriacetic acid (NiNTA) resin (Qiagen) packed in a column for $1 \mathrm{~h}$ at $4^{\circ} \mathrm{C}$. To maximize the purity of the recombinant protein, the 
affinity column was washed with buffers containing a gradient of increasing imidazole concentrations. This comprised four buffers, each containing the basic buffer (50 mM NaH $\mathrm{PO}_{4}, 300 \mathrm{mM} \mathrm{NaCl}$ ) with the addition of imidazole concentrations of $10-20 \mathrm{mM}, 30 \mathrm{mM}$, and $40 \mathrm{mM}$. Each washing step was performed with $10 \mathrm{col}-$ umn volumes of buffer. Finally, the purified recombinant protein was eluted with 10 column volumes of elution buffer $\left(50 \mathrm{mM} \mathrm{NaH} \mathrm{PO}_{4}, 300 \mathrm{mM} \mathrm{NaCl}\right.$, and $250 \mathrm{mM}$ imidazole); this buffer contained an excess of imidazole to allow displacement of the His-tag from nickel coordination, thus the His-tagged recombinant protein was able to be eluted. The protein-containing fractions were pooled and buffer exchanged into PBS containing $1 \mathrm{M}$ urea using a spin column with a $3-\mathrm{kDa}$ molecular weight cut-off (Vivapsin; Sartorius, USA), this was repeated three times. The protein concentration was determined using a commercial protein assay kit $(R C$ $D C^{\mathrm{TM}}$; BioRad, Hercules, CA, USA), and the protein was stored at $-80^{\circ} \mathrm{C}$.

\section{Purification of rUreG under denaturing conditions}

The protein pellet, prepared as described above, was dissolved in $15 \mathrm{~mL}$ of denaturing lysis/binding buffer (7 M urea, $100 \mathrm{mM} \mathrm{NaH} \mathrm{PO}_{4}, 10 \mathrm{mM}$ Tris- $\mathrm{HCl}, \mathrm{pH}$ 8.0) and incubated in a shaker for $15-30 \mathrm{~min}$, then centrifuged at $10,000 \times g$ at $4^{\circ} \mathrm{C}$ for $10 \mathrm{~min}$. DNase I was mixed with the supernatant and incubated on ice for $30 \mathrm{~min}$, then centrifuged at $10,000 \times g$ at $4^{\circ} \mathrm{C}$ for $30 \mathrm{~min}$ and syringe filtered $(0.45 \mu \mathrm{m})$. The supernatant was then incubated with $1 \mathrm{~mL}$ of washed Ni-NTA resin (Qiagen) for $1 \mathrm{~h}$ at $4^{\circ} \mathrm{C}$. The mixture was loaded into a purification column pre-equilibrated with denaturing lysis buffer. The column was washed twice with $10 \mathrm{~mL}$ of denaturing buffer $(8 \mathrm{M}$ urea, $100 \mathrm{mM} \mathrm{NaH}{ }_{2} \mathrm{PO}_{4}, 10 \mathrm{mM}$ Tris- $\mathrm{HCl}, \mathrm{pH}$ 6.1). The recombinant protein was eluted as $500-\mu \mathrm{L}$ fractions with $10 \mathrm{~mL}$ of denaturing elution buffer D (8 M urea, $100 \mathrm{mM}$ $\mathrm{NaH}_{2} \mathrm{PO}_{4}, 10 \mathrm{mM}$ Tris-Cl, pH 5.9) and the protein content was confirmed using a protein assay kit (Bio-Rad). More fractions were collected using elution buffer E (8 M urea, $100 \mathrm{mM} \mathrm{NaH} \mathrm{PO}_{4}, 10 \mathrm{mM}$ Tris-Cl, pH 4.5) until no more protein was observed. The purified fractions were pooled and buffer-exchanged five times (as described above) into storage buffer containing $50 \mathrm{mM}$ Tris- $\mathrm{HCl}$, $150 \mathrm{mM} \mathrm{NaCl}$, and 5\% glycerol. The protein concentration was determined using a commercial protein assay $\left(R C D C^{\mathrm{TM}}\right.$, BioRad), and the protein was stored at $-80^{\circ} \mathrm{C}$.

\section{Serum samples}

The serum samples were first tested using a commercial H. pylori IgG-ELISA kit (Adaltis, Bologna, Italy) and divided into several categories on the basis of their serological profiles. Group I: serum samples from patients whose biopsy cultures were positive for $H$. pylori and
anti-H. pylori IgG antibodies $(\mathrm{n}=30)$. This group comprised two patients with duodenal ulcers, five patients with gastric ulcers, 20 patients with gastritis, and three patients with normal scope findings. Group II: serum samples from healthy individuals with no history of gastric disorders $(n=10)$. Group III: serum samples from patients with gastrointestinal complaints who were referred to the endoscopy unit; however, their tissue biopsy cultures were negative for $H$. pylori $(\mathrm{n}=20)$. Group IV: serum samples from people with other diseases, such as typhoid, leptospirosis, E. coli septicemia, shigellosis, Staphylococcus aureus septicemia, and amoebic liver abscess $(\mathrm{n}=10)$. Sera from groups II-IV tested negative for anti- $H$. pylori IgG antibodies and served as control sera. Control sera were previously stored samples from the serum bank at INFORMM (Universiti Sains Malaysia).

\section{SDS-PAGE and western blot analysis}

The recombinant protein preparations were each loaded at $20 \mu \mathrm{g}$ per well onto a $12 \%$ resolving gel, and SDSPAGE was performed at $100 \mathrm{~V}$. The gel was transferred onto a nitrocellulose membrane $(0.45 \mu \mathrm{m}$; BioRad $)$ using a semi-dry transblot (BioRad), then blocked with $5 \%$ alkalisoluble casein overnight at $4^{\circ} \mathrm{C}$. The membrane was then washed four times with Tris-buffered saline containing $0.05 \%$ Tween 20 (TBS-T; $50 \mathrm{mM}$ Tris, $150 \mathrm{mM} \mathrm{NaCl}$, $0.05 \%$ Tween-20). For the detection of histidine-tagged protein, the membrane was incubated with anti-His-HRP (Novagen, Germany) (1:1000) for $1 \mathrm{~h}$ at room temperature. After a washing step, substrate development was performed using enhanced chemiluminescence blotting reagent (Roche Diagnostics, Mannheim, Germany) and Kodak films (Kodak, USA).

For western blotting using the serum samples, after transfer of the recombinant protein onto the nitrocellulose membrane, the membrane was washed four times with TBS-T, then blocked with $1 \%$ blocking solution (Roche Diagnostics) for $1 \mathrm{~h}$ at room temperature on a shaker. After one more wash, the membrane was cut into strips, then incubated at $4^{\circ} \mathrm{C}$ overnight with different groups of serum samples as the primary antibody (1:25 dilution in TBS). Following three washing steps, the strips were incubated with monoclonal mouse antihuman IgG-HRP (1:4000 in TBS; Invitrogen) or monoclonal mouse anti-human IgA-HRP (1:2000 in TBS) for $1 \mathrm{~h}$, followed by washing with TBS-T. Substrate development was performed as described above.

\section{In-gel digestion of proteins and MS-MS analysis}

The recombinant protein band was manually excised from the Coomassie blue-stained gel and destained by incubating with $200 \mu \mathrm{L}$ of destaining solution for $30 \mathrm{~min}$ at $37^{\circ} \mathrm{C}$ with shaking. The gel slice was digested and extracted using the Agilent Protein In-gel Trypsin Digestion Kit 
(Agilent, USA). The sample was then cleaned up using ZipTipC18 pipette tips (Zip-Tip U-C18; Millipore, Bedford, MA, USA), eluted, and concentrated using a vacuum concentrator (Eppendorf, Westbury, NY, USA) until completely dry. The protein was then analyzed using MALDI-TOF-TOF 4800 (ABSCIEX, Foster City, CA, USA).

\section{Production of hyperimmune mice serum against UreG recombinant protein and antigenicity determination}

Pre-immunized serum was obtained from four mice (aged 4-6 weeks) by bleeding from the tail, then pooled for use as control serum [21]. Next, a mixture containing $200 \mu \mathrm{L}$ of Freund's complete adjuvant (CFA) and $200 \mu \mathrm{L}$ of $200 \mu \mathrm{g}$ UreG recombinant antigen was subcutaneously injected into each of the four mice. Two booster injections were given at 2-week intervals, one using Freund's incomplete adjuvant (IFA) mixed with the recombinant antigen and another using the recombinant antigen alone. Blood from each mouse was centrifuged to extract the serum sample. Then, serum samples from all four mice were pooled for use as the primary antibody.

H. pylori lysate antigen and the purified UreG recombinant protein were electrophoresed at $20 \mu \mathrm{g}$ per well on a $12 \%$ SDS-PAGE, then transferred onto nitrocellulose membrane as explained above. The membrane was blocked, washed, cut into strips, and incubated with the pooled mice serum, then probed with monoclonal human anti-mouse IgG-HRP (Invitrogen). The strips were then washed four times with TBS-T and developed using chemiluminescence substrate as described above.

\section{Results}

The presence and orientation of the DNA sequences of the ureG gene in PCR2.1 TOPO and the pRSET constructs was confirmed by performing PCR with the vector and gene-specific primers and DNA sequencing. Figure 1 shows amplification of the ure $G$ gene from the pRSET/ureG recombinant plasmid and excision of this gene from the plasmid using enzymes HindIII and EcoRI. DNA sequence analysis of the TOPO/ureG and pRSET/ureG constructs confirmed that ure $G$ was in the correct reading frame (data not shown).

Figure 2 shows the results of western blot analysis of the purified recombinant protein prepared from the supernatant and pellet of the lysed cells to check for the presence of the six-histidine fusion in the UreG recombinant protein; a thick distinctive band was observed at the expected molecular weight of approximately $28 \mathrm{kDa}$. MALDI TOF-TOF results confirmed the identity of the protein as UreG; with scores of 454 with 10 matched peptides and 462 with six matched peptides from bands excised from SDS-PAGE of native and denatured forms of the recombinant protein, respectively.
Although western blot analysis indicated that the expressed UreG target protein was present in both the supernatant and pellet of the lysed cells, the amount of protein in the pellet (insoluble protein) was $3 \mathrm{mg} / \mathrm{L}$ of culture, compared with $1.4 \mathrm{mg} / \mathrm{L}$ of culture (soluble protein) in the supernatant.

The UreG recombinant protein showed 70\% (21/30) and 60\% (18/30) reactivities with Group 1 sera (culturepositive patients) when probed with anti-human IgGHRP and anti-human IgA-HRP respectively. When the results of the IgG and IgA western blots were combined, the positive reactivity rate was $83.3 \%(25 / 30)$. Among the control sera (Groups II, III, and IV), $97.5 \%$ and 92.5\% were not reactive when probed with anti-human IgG-HRP and anti-human IgA-HRP, respectively.

Both the H. pylori lysate antigen and purified UreG recombinant protein displayed a distinctive band at the expected molecular weights of $25 \mathrm{kDa}$ and $28 \mathrm{kDa}$ respectively when probed with hyperimmune mice serum (Figure 3). This demonstrated that the polyclonal antibody against UreG recombinant protein was recognized by both native and recombinant UreG proteins.

\section{Discussion}

Several virulence-associated genes have been identified in H. pylori and these are believed to play a major role in the pathogenesis of this organism. The proteins expressed by some of these genes, such as UreB, VacA, CagA, HspB, FlaA, FlaB, and outer membrane proteins, have been investigated as diagnostic indicators of $H$. pylori infection $[7,8,19,22]$.

The production of a wide range of proteins was previously unattainable because of the limitations imposed by the use of native proteins. In recent times however, advances in recombinant technology have made it possible to produce a wide range of defined antigens in large quantities for use in diagnostic applications. For H. pylori, a variety of recombinant protein antigens, such as rUreB, rVacA, rCagA, rHpaA, rNapA, rFlaA, and rFlaB, have been constructed, expressed, and purified by affinity chromatography. These recombinant antigens could improve serodiagnosis of $H$. pylori infection, replacing the complex native $H$. pylori antigens [23-25]. In one study, rUreB was used as the antigen in ELISA to identify a specific antibody in serum samples from $H$. pylori-infected patients. In addition, the anti-rUreB rabbit polyclonal antibody was used to study UreB expression in different $H$. pylori isolates. A specific antibody against rUreB in the sera of H. pylori-infected patients and high frequencies of UreB expression in various $H$. pylori isolates indicated that rUreB is a good antigen candidate for developing H. pylori diagnostic tests and vaccines [26]. Furthermore, combinations of purified $\mathrm{rUreA} / \mathrm{rUreB}$ have been shown to induce H. pylori-specific responses in human volunteers [27]. 


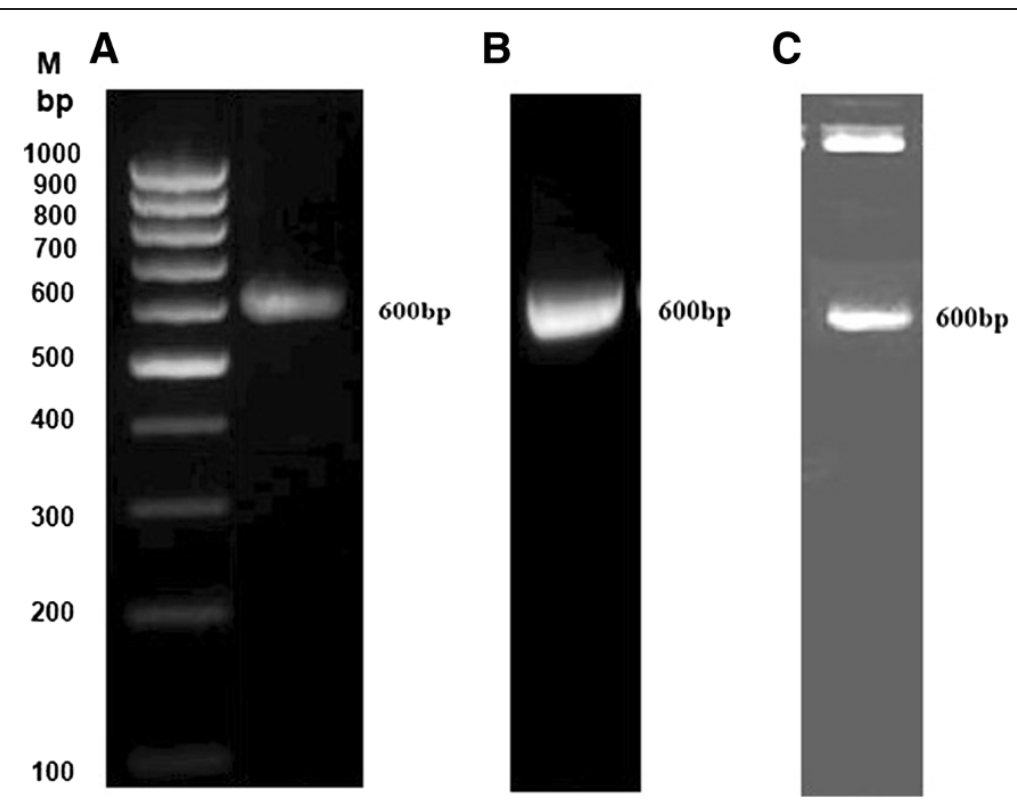

Figure 1 PCR amplification of the ureG gene and verification of the recombinant prokaryotic expression plasmid pRSET-ureG. A: PCR amplification of the ureG gene $\mathbf{B}$ : PCR screening of the PRSET/ureG recombinant $\mathbf{C}$ : Digestion product of pRSET/ureG with HindIII and EcoRI $\mathbf{M}$ : 100 bp DNA ladder.

The ureG gene is a member of the ure gene cluster, and its encoded protein is expressed as an accessory protein required for nickel ion insertion into the apoenzyme of urease [26,28]. In the biosynthesis process of the active metal-bound form of urease (a nickel-dependent enzyme), a lysine carbamate functional group is formed alongside the delivery of two $\mathrm{Ni}^{(2+)}$ ions into the precast active site of the apoenzyme $[15,29]$. UreG plays the role of chaperone in the urease active site assembly and is required to complete the biosynthesis of the nickel enzyme [15]. However, prior to

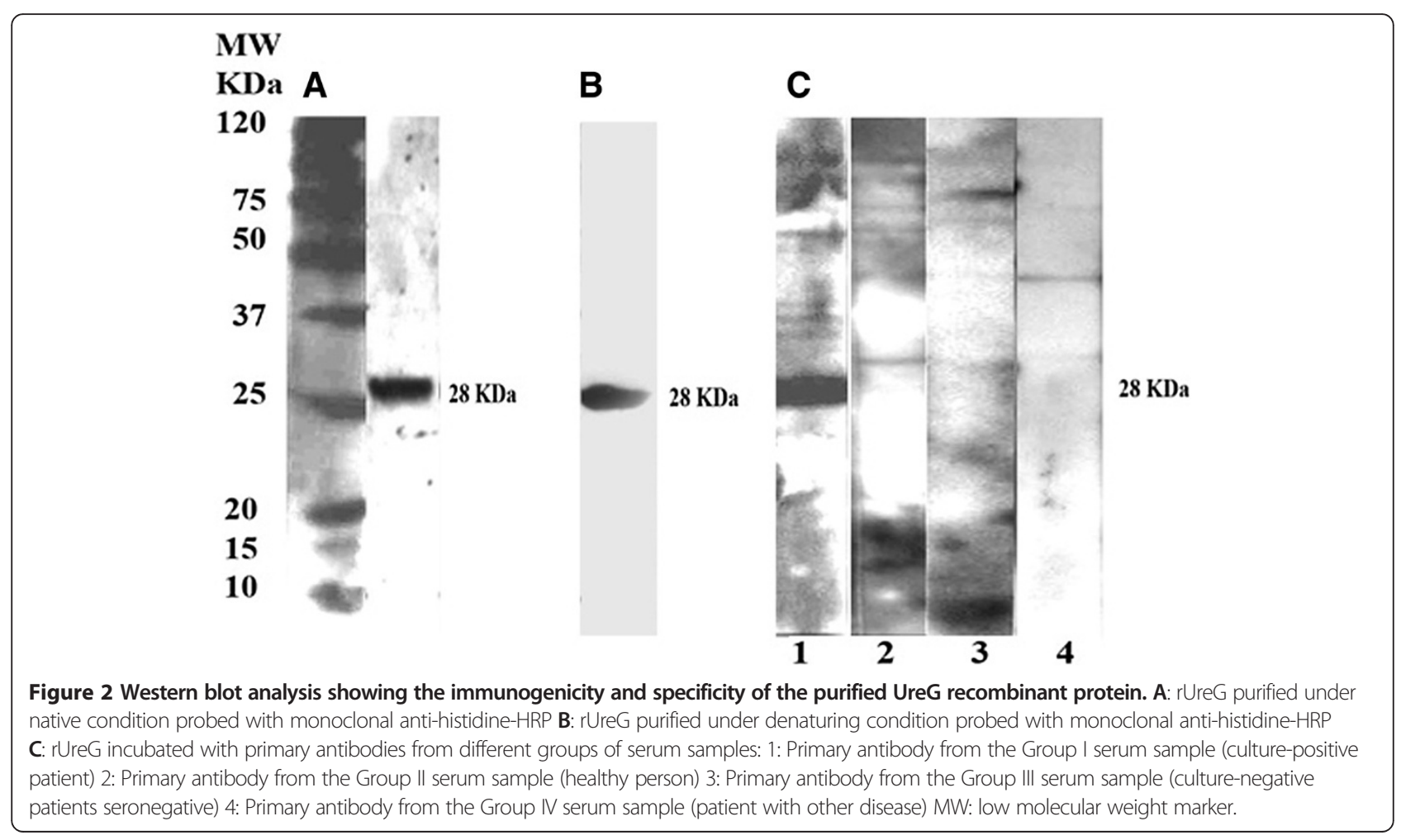




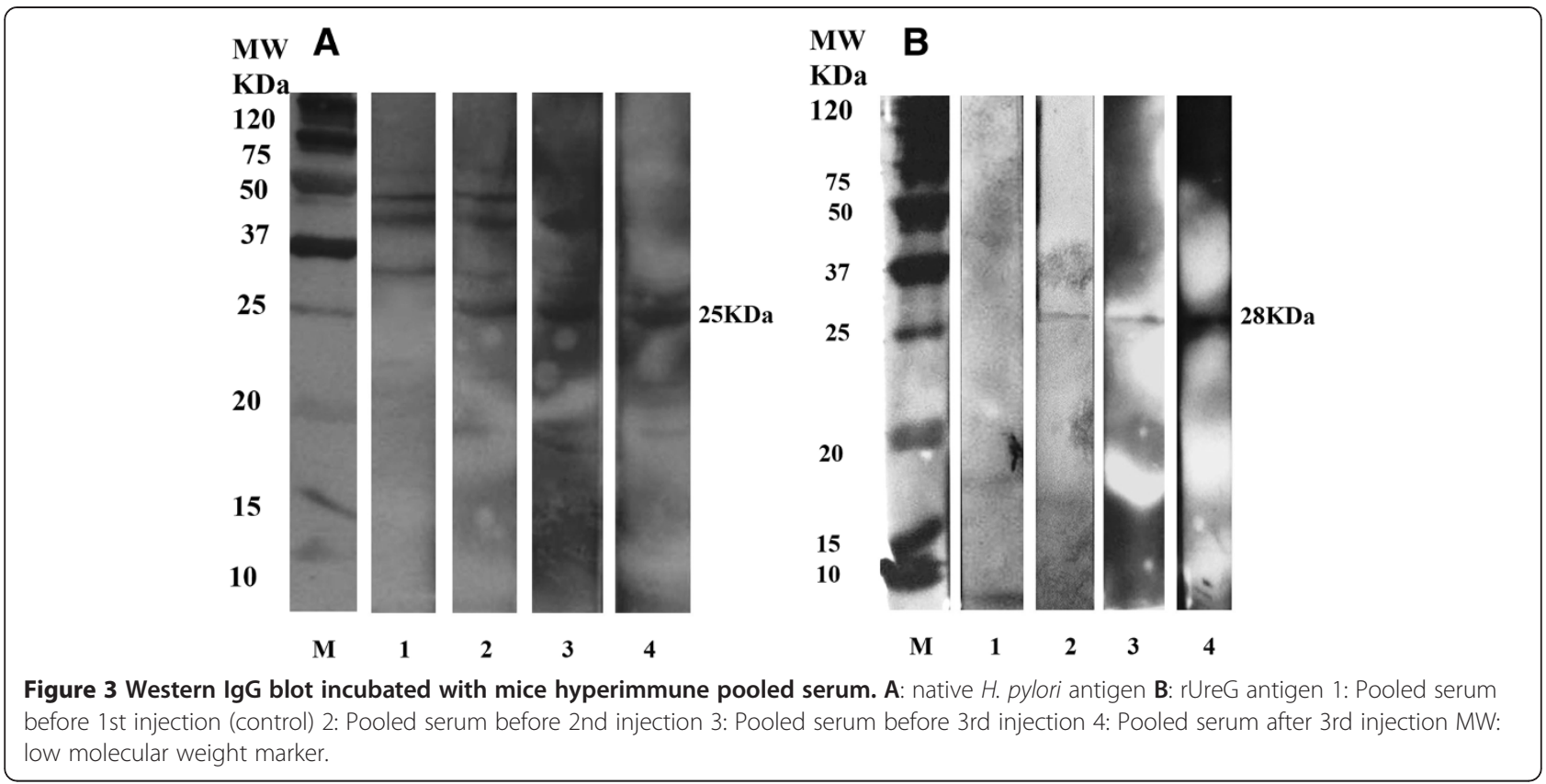

our last report [14], UreG has not been described in terms of its potential as a diagnostic marker of $H$. pylori infection.

In the present study, rUreG was produced as both a soluble and insoluble protein, thus purification was performed under both native and denaturing conditions; however, the yield of the latter was almost twice that of the former. On the IgG and IgA western blot analysis, the reactivities of soluble rUreG were $70 \%$ and $60 \%$, respectively, with sera from culture-positive patients. A combination of the IgG and IgA western blots gave a higher rate of reactivity of $83.3 \%(25 / 30)$. In comparison, in our previous study, the native UreG protein showed $73.3 \%(22 / 30)$ and $63.3 \%(19 / 30)$ reactivities when probed with IgG and IgA, respectively; while a combination of the IgG and IgA western blots showed $87 \%$ reactivity [14]. Thus, the diagnostic sensitivities of the native and recombinant forms of the UreG protein were similar. The specificity of the rUreG was found to be 97.5\% and $92.5 \%$ when probed with anti-human IgGHRP and anti-human IgA-HRP, respectively. In comparison, native UreG showed $100 \%$ specificity [14]. The reason for the higher specificity of native UreG compared with rUreG is not known. Mapping the epitope of the recombinant protein or the use of a peptide-based assay may lead to increased specificity of the recombinant protein.

Studies with urease showed that it yielded protection in only about $80 \%$ of immunized mice [30]. In a Helicobacter felis model, oral immunization in mice was performed with a combination of recombinant $H$. pylori heat-shock protein A (HspA) and urease; this dual antigen immunization induced $100 \%$ protection against $H$. pylori infection [31,32]. This indicated that the combination of multiple antigens can be effective in the development of a good protective vaccine against $H$. pylori infection [30,31]. Similarly, in another study, immunization with $\mathrm{rHpaA}$ or rUreB alone was found to induce weak immune responses; however, when both antigens were pooled, together with cholera toxin, strong immune responses were produced that induced protection against $H$. pylori infection [32,33]. Because, in this study, rUreG has been shown to be immunogenic in mice, it should also be investigated for its potential as a vaccine candidate.

Similar to the multiple antigen concept mentioned above, in some commercial diagnostic kits, a mixture of antigens is used because it provides higher sensitivity and specificity compared with using a single antigen [17,34-37]. This approach is further justified by reported findings that the sensitivity of some diagnostic kits varied depending on geographical location, with possible reasons being $H$. pylori strain heterogeneity, cross-reactivity with other intestinal pathogens, and varying immunological responses to $H$. pylori antigens in different patient populations [38-40]. In this study, although rUreG showed good seroreactivity to $H$. pylori patients' sera, it did not show sufficiently high sensitivity to be used as a single antigen. Therefore, rUreG in combination with other potential diagnostic markers, such as rCagA, rUreB, and/or rVacA, may be investigated as a cocktail diagnostic reagent for the development of a robust test for $H$. pylori infection with effective worldwide application. Future studies should also be performed to evaluate the usefulness of rUreG in distinguishing the different clinical presentations of $H$. pylori infection, i.e., acute symptoms (such as duodenal ulcer or gastric cancer), chronic symptoms (such as dyspepsia), or 
no symptoms. The development of an ELISA using rUreG would be the preferred method for an effective diagnostic assay, however, further work to increase the purity of the recombinant protein may be required to maintain its high diagnostic specificity.

\section{Conclusion}

In this study, the full-length, open reading frame of the 25$\mathrm{kDa}$ UreG protein of $H$. pylori, a potential diagnostic marker, was cloned into the TOPO-TA vector, and subcloned into the pRSET expression vector. The recombinant form of the UreG protein showed high reactivity with H. pylori patients' sera and no reactivity with most other sera, as well as good immunogenicity in mice. Thus, rUreG is a promising candidate for the diagnosis of $H$. pylori infection, either singly, or in combination with other diagnostic reagents.

\section{Competing interests}

The authors have no competing interest in this article.

\section{Authors' contributions}

AK participated in the study design, performed the experiments and data analysis, and wrote the first draft of the paper; SO performed ELISA on the serum samples and participated in sample categorization; MHY helped in upscaling of the recombinant protein and in the mice immunization experiments; AS acquired the funding, organized and supervised the serum sample collection; VN participated in sample collection and categorization; RN designed and supervised the whole study, including data analysis and interpretation, performed the major editing of the manuscript, and helped in the acquisition of funding. All authors participated in the writing and editing of the manuscript. All authors read and approved the final manuscript.

\section{Acknowledgments}

This study was funded by Universiti Sains Malaysia Research University grants: No. 1001/PPSP/8120162, 1001/CIPPM/811086, and 1001/CIPPM/ 844084. The authors would like to thank Dr. Kotresha and Dr. Nurul Hasanah from the Institute for Research in Molecular Medicine (Universiti Sains Malaysia) for their technical assistance.

\section{Author details}

${ }^{1}$ Institute for Research in Molecular Medicine (INFORMM), Universiti Sains Malaysia, 11800, Minden, Penang, Malaysia. ${ }^{2}$ Hospital Seberang Jaya, Penang, Malaysia.

Received: 31 October 2013 Accepted: 31 October 2014

Published: 18 November 2014

\section{References}

1. Benoit S, Mehta N, Wang G, Gatlin M, Maier RJ: Requirement of hydD, hydE, hypC and hypE genes for hydrogenase activity in Helicobacter pylori. Microb Pathog 2004, 36(3):153-157.

2. Blaser MJ: Helicobacter pylori and gastric diseases. BMJ 1998, 316(7143):1507-1510.

3. Lin L-L, Chen C-N, Lin W-C, Lee P-H, Chang K-J, Lai Y-P, Wang J-T, Juan H-F: Annexin A4: a novel molecular marker for gastric cancer with Helicobacter pylori infection using proteomics approach. Proteomics Clin App/ 2008, 2(4):619-634.

4. Goto T, Nishizono A, Fujioka T, Ikewaki J, Mifune K, Nasu M: Local secretory immunoglobulin A and postimmunization gastritis correlate with protection against Helicobacter pylori infection after oral vaccination of mice. Infect Immun 1999, 67(5):2531-2539.

5. Franceschi F, Gasbarrini A: Helicobacter pylori and extragastric diseases. Best Pract Res Clin Gastroenterol 2007, 21(2):325-334.
6. Robinson $\mathrm{K}$, Argent $\mathrm{RH}$, Atherton JC: The inflammatory and immune response to Helicobacter pylori infection. Best Pract Res Clin Gastroenterol 2007, 21(2):237-259.

7. Cremonini F, Gabrielli M, Gasbarrini G, Pola P, Gasbarrini A: The relationship between chronic $H$. pylori infection, CagA seropositivity and stroke: meta-analysis. Atherosclerosis 2004, 173(2):253-259.

8. Schumann C, Triantafilou K, Rasche FM, Moricke A, Vogt K, Triantafilou M, Hahn P, Schneider EM, Lepper PM: Serum antibody positivity for distinct Helicobacter pylori antigens in benign and malignant gastroduodenal disease. IJMM 2006, 296(4-5):223-228.

9. Czinn SJ, Cai A, Nedrud JG: Protection of germ-free mice from infection by Helicobacter felis after active oral or passive IgA immunization. Vaccine 1993, 11(6):637-642.

10. Akhiani AA, Schon K, Franzen LE, Pappo J, Lycke N: Helicobacter pylorispecific antibodies impair the development of gastritis, facilitate bacterial colonization, and counteract resistance against infection. J Immunol 2004, 172(8):5024-5033.

11. Argent $\mathrm{RH}$, Atherton JC: Helicobacter pylori dupA is not associated with duodenal ulcers in populations from South Africa, Scotland, China and USA. Gut 2007, 56:A54-A55.

12. She RC, Wilson AR, Litwin CM: Evaluation of Helicobacter pylori immunoglobulin $\mathrm{G}(\mathrm{lg} \mathrm{G})$, $\lg \mathrm{A}$, and $\lg \mathrm{M}$ serologic testing compared to stool antigen testing. Clin Vaccine Immunol 2009, 16(8):1253-1255.

13. Zúñiga-Noriega JR, Bosques-Padilla FJ, Pérez-Pérez Gl, Tijerina-Menchaca R, Flores-Gutiérrez JP, Maldonado Garza HJ, Garza-González E: Diagnostic utility of invasive tests and serology for the diagnosis of Helicobacter pylori infection in different clinical presentations. Arch Med Res 2006, 37(1):123-128

14. Khalilpour A, Santhanam A, Wei LC, Saadatnia G, Velusamy N, Osman S, Mohamad AM, Noordin R: Antigenic proteins of Helicobacter pylori of potential diagnostic value. Asian Pac J Cancer Prev 2013, 14(3):1635-1642.

15. Zambelli B, Turano P, Musiani F, Neyroz P, Ciurli S: Zn2+-linked dimerization of UreG from Helicobacter pylori, a chaperone involved in nickel trafficking and urease activation. Prot Struct Funct Bioinform 2009, 74(1):222-239.

16. Chan CH, Ko CC, Chang JG, Chen SF, Wu MS, Lin JT, Chow LP: Subcellular and functional proteomic analysis of the cellular responses induced by Helicobacter pylori. Mol Cell Proteomics 2006, 5(4):702-713.

17. Andersen LP, Espersen F: Immunoglobulin G antibodies to Helicobacter pylori in patients with dyspeptic symptoms investigated by the western immunoblot technique. J Clin Microbiol 1992, 30(7):1743-1751.

18. Wang XF, Wang KX: Cloning and expression of vacA gene fragment of Helicobacter pylori with coccoid form. J Chin Med Assoc 2004, 67(11):549-556.

19. Zheng J, Xiao- Hong T, Huang A-L, Wang P-L: A study of recombinant Protective H. pylori antigens. World J Gastroenterol 2002, 8(2):308-311.

20. Khalilpour A, Santhanam A, Wei LC, Mohammad A, Osman S, Noordin R: Helicobacter pylori proteins with diagnostic potential identified using proteomic approach. Int J Infect Dis 2012, 16(Suppl 1):396-397.

21. Feng S, Hodzic E, Kendall LV, Smith A, Freet K, Barthold SW: Cloning and expression of a Helicobacter bilis immunoreactive protein. Clin Diagn Lab Immunol 2002, 9(3):627-632.

22. Michetti PKC, Kotoff K, Porta N, Blanco JL, Bachmann D, Herranz M, Saldinger P, Corthesy-Theulaz I, Losonsky G, Nichols R, Simon J, Stolte M, Ackerman S, Monath TP, Blum AL: Oral immunization with urease and Escherichia coli heat-labile enterotoxin is safe and immunogenic in Helicobacter pylori-infected adults. Gastroenterology 1999, 116(4):804-812.

23. Angelini A, Tosi T, Mas P, Acajjaoui S, Zanotti G, Terradot L, Hart DJ: Expression of Helicobacter pylori CagA domains by library-based construct screening. FEBS J 2009, 276(3):816-824.

24. Yan J, Mao YF, Shao ZX: Frequencies of the expression of main protein antigens from Helicobacter pylori isolates and production of specific serum antibodies in infected patients. World J Gastroenterol 2005, 11(3):421-425

25. Gu Q, Han N, Liu J, Zhu M: Expression of Helicobacter pylori urease subunit B gene in transgenic rice. Biotechnol Lett 2006, 28(20):1661-1666.

26. Mao YF, Yan J: Construction of prokaryotic expression system of ureB gene from a clinical Helicobacter pylori strain and identification of the recombinant protein immunity. World J Gastroenterol 2004, 10(7):977-984.

27. Banerjee S, Medina-Fatimi A, Nichols R, Tendler D, Michetti M, Simon J, Kelly CP, Monath TP, Michetti P: Safety and efficacy of low dose Escherichia coli 
enterotoxin adjuvant or urease based oral immunisation against Helicobacter pylori in healthy volunteers. Gut 2002, 51(5):634-640.

28. Mobley HL: The role of Helicobacter pylori urease in the pathogenesis of gastritis and peptic ulceration. Aliment Pharmacol Ther 1996, 10(Suppl 1):57-64.

29. Stingl K, Schauer K, Ecobichon C, Labigne A, Lenormand P, Rousselle JC, Namane A, de Reuse H: In vivo interactome of Helicobacter pylori urease revealed by tandem affinity purification. Mol Cell Proteomics 2008, 7(12):2429-2441.

30. Blanchard T, Nedrud J: 9. Helicobacter Pylori vaccine. In Helicobacter Pylori in the $21^{\text {st }}$ Century. Edited by Philip S, Mitchell HM. Wallingford, Oxforshire, UK: CABI; 2010:167-168.

31. Ferrero RL, Thiberge JM, Kansau I, Wuscher N, Huerre M, Labigne A: The GroES homolog of Helicobacter pylori confers protective immunity against mucosal infection in mice. PNAS 1995, 92(14):6499-6503.

32. Flach CF, Svensson N, Blomquist M, Ekman A, Raghavan S, Flach JH: A truncated form of $\mathrm{HpaA}$ is a promising antigen for use in a vaccine against Helicobacter pylori. Vaccine 2011, 29(6):1235-1241.

33. Nystrom J, Svennerholm AM: Oral immunization with HpaA affords therapeutic protective immunity against $\mathrm{H}$. pylori that is reflected by specific mucosal immune responses. Vaccine 2007, 25(14):2591-2598.

34. Manes G, Zanetti MV, Piccirillo MM, Lombardi G, Balzano A, Pieramico O: Accuracy of a new monoclonal stool antigen test in post-eradication assessment of Helicobacter pylori infection: comparison with the polyclonal stool antigen test and urea breath test. Dig Liver Dis 2005, 37(10):751-755.

35. Simor AE, Lin E, Saibil F, Cohen L, Louie M, Pearen S, Donhoffer HA: Evaluation of enzyme immunoassay for detection of salivary antibody to Helicobacter pylori. J Clin Microbiol 1996, 34(3):550-553.

36. Pelerito A, Oleastro M, Lopes Al, Ramalho P, Cabral J, Monteiro L: Evaluation of rapid test Assure Helicobacter pylori for diagnosis of H. pylori in pediatric population. J Microbiol Methods 2006, 66(2):331-335.

37. Glassman MS, Dallal S, Berezin SH, Bostwick HE, Newman L, Perez-Perez GI, Blaser MJ: Helicobacter pylori-related gastroduodenal disease in children. Diagnostic utility of enzyme-linked immunosorbent assay. Dig Dis Sci 1990, 35(8):993-997.

38. Ohtsuka Y, Shimada T, Watanabe N, Akiyama H, Suzuki Y, Ishida M, Hiraishi $H$, Terano A: Analysis of the vacA gene sequences among Helicobacter pylori strains isolated from Japanese patients[abstract]. Gastroenterology 1997, 112:A243.

39. Khanna B, Cutler A, Israel NR, Perry M, Lastovica A, Fields PI, Gold BD: Use caution with serologic testing for Helicobacter pylori infection in children. J Infect Dis 1998, 178:460-465.

40. Tay CY, Mitchell H, Dong QJ, Goh KL, Dawes IW, Lan RT: Population structure of Helicobacter pylori among ethnic groups in Malaysia: recent acquisition of the bacterium by the Malay population. BMC Microbiol 2009, 9:126

doi:10.1186/1756-0500-7-809

Cite this article as: Khalilpour et al: Helicobacter pylori recombinant UreG protein: cloning, expression, and assessment of its seroreactivity. BMC Research Notes 2014 7:809.

\section{Submit your next manuscript to BioMed Central and take full advantage of:}

- Convenient online submission

- Thorough peer review

- No space constraints or color figure charges

- Immediate publication on acceptance

- Inclusion in PubMed, CAS, Scopus and Google Scholar

- Research which is freely available for redistribution 